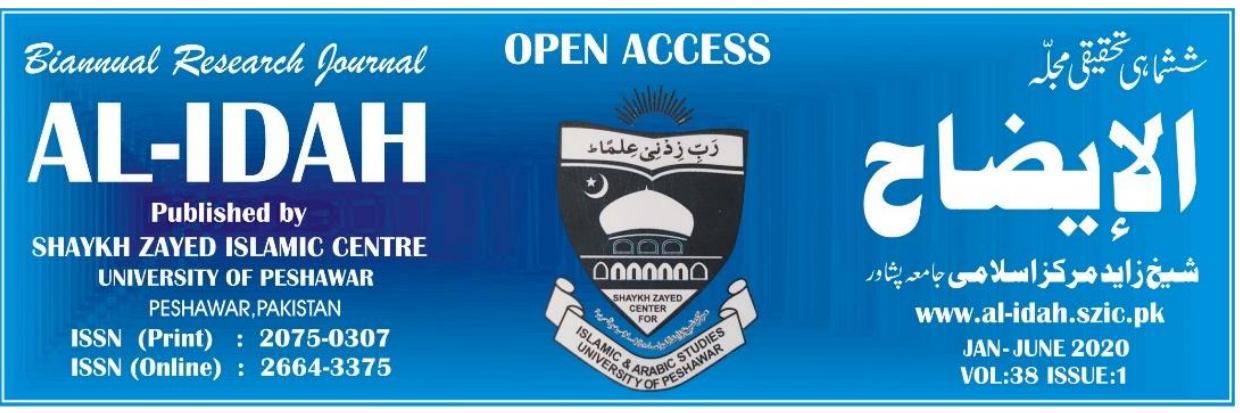

\title{
The Role of Islamic Courts in Land Reforms in Pakistan
}

\author{
Dr Ataullah Kahn Mahmood \\ Assistant Professor Law, Department of Law International Islamic \\ University Islamabad
}

\section{Ghufran Ahmad}

PhD Scholar, Department of Law International Islamic University Islamabad

\section{Article DOI: https://doi.org/10.37556/al-idah.038.01.0626}

\section{Abstract}

A vast majority of Muslim scholars opine that land reforms including the fixation of ceiling on individual land-holdings can be carried out without offending any Islamic teachings. Moreover, article 253 of the Constitution empowers the Parliament to prescribe the maximum limits as to property or any class thereof which may be owned, held, possessed or controlled by any person. Likewise, such reforms are considered essential as for as requirements of distributive justice is concerned and to further the desired Islamic goals of social justice, eradication of social evils and to ensure economic wellbeing of the poor attached to earth. To achieve these desired goals, land reforms laws were introduced in the country. However, the beneficiaries of feudalism and landlordism challenged these laws in the Islamic Courts to protect their vested interests. These judicial forums were split in their findings regarding the fate of these laws. This article analyses the findings of these forums to suggest that weather those who uphold these laws have stronger reasons.

Key words: Land reforms, Distributive Justice, Federal Shari'at Court, jurisdiction, social justice, social evils, economic wellbeing.

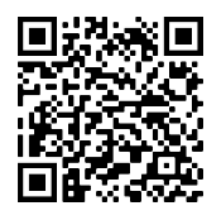

Scan for Download

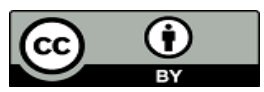




\section{Introduction:}

This effort analyses the role of the Federal Shari'at Court (FSC) and that of the Shari'at Appellate Bench of the Supreme Court of Pakistan (SAB) with respect to the land reforms including the fixation of a ceiling on individual land-holdings in Pakistan. These judicial forums have been referred as the Islamic Courts. The role of these forums came into light after the judgment of the SAB in Qazalbāsh Waqf case. $^{(1)}$

It is interesting to note that Nasim Hassan Shah J., a member of the SAB in Qazalbāsh Waqf case, while throwing light on the importance of land reforms acknowledged that the same are necessary for providing social justice to the people. Moreover, he admitted that if such reforms are not carried out, a number of social evils may take place in the society. He is of the view that these reforms are purely Islamic in their character. ${ }^{(2)}$

However, the SAB in the above referred case held certain provisions of the Land Reforms Regulation, 1972 and the Land Reforms Act, 1977, inter alia, pertaining to the fixation of a ceiling on individual land-holdings repugnant to the injunctions of Islam. ${ }^{(3)}$ Since then, it has been presumed, though erroneously, that the land reforms are un-Islamic. Islam is considered a very sensitive issue in Pakistan. This is one of the reasons that no regime has made any serious efforts to carry out such reforms and hence to put an end to the miseries and sufferings of large classes of the village community even within the parameters of this judgment.

In this article, it has been argued that the SAB did not have the jurisdiction in the first place, to declare the provisions of the 1972 Regulation and the 1977 Act imposing ceiling on land-holdings repugnant to the injunctions of Islam. This argument is built by analyzing the judgments of the FSC and the SAB in Hafiz Muhammad Ameen and Qazalbāsh Waqf cases respectively. ${ }^{(4)}$ Apart from the issue of jurisdiction and fixation of ceiling, some other important issues analyzed in this article include whether the State can acquire property from the citizens without paying compensation to them or whether the courts are competent to exercise jurisdiction in this regard, whether the state can intervene to limit the grounds of eviction in spite of the existence of a tenancy agreement between the landlord and a tenant, and so on. As is known, a final decision of the SAB is open to review under article 188 of the Constitution. Therefore, in order to analyze the role of Federal Shari'at Court and Shari'at Appellate Bench of the Supreme Court of Pakistan with respect to land reforms comprehensively, the review judgment rendered by the SAB in Qazalbāsh Waqf case is also analyzed here.

There is another perspective of this discussion if it is looked into through the prism provided by the Supreme Court of Pakistan that is in Hakim Khan Case (PLD 1992 SC 595), it was held that no doubt Objective Resolution has become the part of the Constitution but it is not Supra Constitutional Provision. If there is inconsistency between the provision of the Constitution and the same exceeds the limit prescribed by Almighty Allah, the matter can be brought to the notice of Parliament, which alone is competent to amend the Constitution and remedial legislation to bring the impugned provision in conformity with the injunctions of 
Islam. It was further observed that Article 2(a) was never intended to be selfexplanatory document. The Court cannot strike down Article 45 of the Constitution even if the same is repugnant to Holy Qur'an and Sunnah. Howevr, we restrict the discussion to the judgments of the FSC and SAB of the SCP.

\section{Hạāiz Muhammad Amīn and Qazalbāsh Waqf Cases:}

In Hāfiz Muhammad Ameen case, the FSC disposed of sixty seven Shari'at Petitions by a single judgment since common legal issues were involved in these petitions. The petitioners had invoked the original jurisdiction of the FSC under article 203D of the Constitution by challenging certain provisions of different laws being repugnant to the injunctions of Islam hence void. These laws included the Land Reforms Regulation, 1972, the Land Reforms Act, 1977, the Punjab Preemption Act, 1913, the N.W.F.P. Pre-emption Act, 1950, the Punjab Acquisition of Land (Housing) Act, 1973, the Development of Cities Act, 1976 and the Capital Development Ordinance, 1960. However, while analyzing Hafiz Muhammad Ameen case, the discussion is restricted to the provisions of the land reforms laws and the analysis of the provisions of other laws has not been discussed here.

The above mentioned Shari'at Petitions were heard and disposed of by a full Court consisting of five judges.. All the judges wrote their separate notes while the main judgment was authored by Aftab Hussain J. Following the majority view all the petitions were dismissed though the reasons for such dismissal were different for different members.

This dismissal order passed by the FSC was challenged by several petitioners invoking the appellate jurisdiction of the SAB under article 203F. The SAB disposed of these different appeals in 1989 by a single judgment reported as Qazalbāsh Waqf and others versus Chief Land Commissioner, Punjab, Lahore and others. ${ }^{(5)}$ These appeals were heard by five judges of the SAB. The Bench was headed by Muhammad Afzal Zullah J. Other members included Nasim Hassan Shah, Shafiur Rehman, Pir Muhammad Karam Shah and Mawlāna Muhammad Taqī Usman̄i JJ. The appeals were accepted by a majority of three to two members. Pir Muhammad Karam Shah not in clear word, rather can be molded to other side as well and Mawlāna Muhammad Taqī Usman̄̄ JJ. concluded almost same though each wrote his own separate judgment. Muhammad Afzal Zullah J. concurred with them to give them a majority. Nasim Hassan Shah and Shafiur Rahman JJ. wrote separate dissenting notes.

3. Fixation of Ceiling, Compensation for Surrendered Land and the Issue of Jurisdiction:

Article 253 of the Constitution, on the one hand, impresses the authority of the Parliament to legislate a law that may fix a ceiling on property to be owned, held, possessed or controlled by an individual. On the other hand, it declares void any law that may allow an individual to hold property in excess of the ceiling fixed by the law. Thus, it restricts the authority of the Parliament to legislate such a law. It is worth mentioning that similar provisions were also contained in the form of articles 217 and 269 in the Constitution of 1962 and the Interim Constitution of 1972 respectively. Such a power specifically given to the Parliament in spite of its 
general competence to legislate suggests very strongly the firm determination of the makers of the Constitution to eradicate social evils and promote social justice and economic wellbeing of people by eradicating Jāgirdārī system. Paragraphs 8 and 10 of the 1972 Regulation and Section 3 the 1977 Act which impose a ceiling on individual land-holdings were made under the specific mandate of article 253 of the Constitution and other similar provisions in the earlier Constitutions. The FSC with a majority of four to one held that it did not have the jurisdiction to declare the said provisions repugnant to the injunctions of Islam. Aftab Hussain J. elaborately explained the grounds which had made the said provisions immune from the jurisdiction of the FSC under article 203D.

The provisions of the 1972 Regulation were enforced on 11 March 1972. At this time the country was governed under the Martial Law which had been imposed since 25 March 1969. The Constitution of 1962 had been abrogated while the Interim Constitution of 1972 had yet to be enforced on 21 April 1972. Meanwhile, the Lahore High Court on 17 April 1972 declared the imposition of Martial Law of 1969 null and void in Zia-ur-Rehman case ${ }^{(6)}$ and . The Martial Law regime was declared usurper and all laws including the 1972 Regulation having been made without lawful authority. Similarly, the Supreme Court on 20 April 1972 had taken the same view with respect to the imposition of 1969 Martial Law in Asma Jillani case. ${ }^{(7)}$ In order to provide sanctity to the 1972 Regulation, various provisions were added in the Interim Constitution, 1972. ${ }^{(8)}$ Thus, article 280(3), inter alia, provided protection to this Regulation by declaring the same to be an existing law. Furthermore, it restricted the authority of the legislature to amend or repeal the said Regulation. Hence, no such action could be taken by the Parliament with respect to this Regulation without the previous sanction of the President in this regard. Besides, as mentioned above article 269 of the Interim Constitution curtailed the authority of the Parliament to legislate any law that would have the effect of increasing the ceiling imposed on the holding of property by this Regulation. Any such law had been declared void by the said article.

Apart from the protection provided to the 1972 Regulation by the provisions of the Interim Constitution, the present Constitution ${ }^{(9)}$ also provides it sufficient protection. In this regard, articles 268(2) and 269 are worth mentioning here. The former was very similar to article 280(3) of the Interim Constitution of 1972 discussed above. This article curtailed the authority of the Parliament to repeal or amend any law provided in the $6^{\text {th }}$ Schedule without the previous sanction of the President. The Land Reforms Regulation, 1972 was mentioned at Serial No. 13. (10) The latter article i.e. 269 provides a blanket protection, inter alia, to all Martial Law Regulations made between 20 December 1971 and 20 April 1972. The Land Reforms Regulation 1972 is one of such Martial Law Regulations. This provision declares that notwithstanding any judgment of any court all Martial Law Regulations and other instruments having the force of law made between the said dates have been validly made by the competent authority. These laws cannot be challenged in any court on any ground whatsoever. Similarly, the orders made, proceedings taken and acts done between the said dates by any authority or any 
person deriving powers from any law made between the said dates are deemed valid and unquestionable in any court.

The Land Reforms Act, 1977 was enacted by the elected Parliament by exercising its legislative powers provided under article 253 of the Constitution. The effect of clause 2 of this article is that the Parliament cannot even by a legislative action increase the ceiling fixed by law though it can further reduce the same. This was the effect of Section 3 of the 1977 Act which reduced the ceiling from 300 acres of unirrigated land to 200 acres and from 150 acres of irrigated land to 100 acres. Similarly, it reduced the permissible measurement of area of land which was previously equivalent to 15000 Produce Index Units (PIU) but was reduced equivalent to 8000 PIU. Aftab Hussain J. in his leading judgment throws light on the objects of these provisions as well. Generally, these have been incorporated to fulfill the Constitutional commands of eradication of social evils and getting social justice as well as promotion of social and economic wellbeing of people. The judgment points out that the objectives behind these provisions are reduction of feudalism, elimination of absentee landlordism, prevention of concentration of natural resources in few hands and to get maximum production out of land. ${ }^{(11)}$

Paragraph 13 of the 1972 Regulation, ${ }^{(12)}$ inter alia, provides that the land above the ceiling is to be surrendered and the same vests in the Government without any compensation. Likewise, Section 9 of the 1977 Act $^{(13)}$ provides the same. However, Section 11 of this Act provides the compensation for the land surrendered under Section 9 at the rate of Rupees 30 per PIU. This compensation is uniform for all the surrendered land. Obviously, it may be well below the market value of the land in certain areas. In order to provide protection to these provisions which apparently seem inconsistent with the fundamental rights, various provisions were made part of the Interim Constitution of 1972 and the present Constitution.

Article 7 of the Interim Constitution ${ }^{(14)}$ generally declared all laws void if made inconsistent with the fundamental rights provided by the Interim Constitution. However, clause 3(b) exempted certain laws from the operation of this provision. Land Reforms Regulation, 1972 was one such law. Similarly, article 21 of this Constitution provided protection to property. Therefore, no property could be compulsorily acquired or taken possession of. This provision, however, was not absolute. A property could be acquired against the wishes of the owner for a public purpose such as housing facility. Moreover, this provision was not applicable to existing laws. The Land Reforms Regulation 1972, of course, was an existing law. In order to acquire property for a public purpose, the action should be backed by a law which should provide for the payment of compensation to the owner as fixed by such law. Such a law instead of fixing compensation can also provide for the principles and the manner according to which such compensation should be paid. Importantly, clause 4 of article 21 barred the jurisdiction of courts to adjudicate upon any matter related to the adequacy or otherwise of the compensation.

The present constitution contains similar provisions in the form of articles 8 and 24. Likewise, clause 3 of article 8 excludes certain laws either conditionally or 
absolutely from the operation of the first two clauses of this article which provide for the nullity of a law being inconsistent with the fundamental rights.

Suffice is to say that the principle of inconsistency with the fundamental rights hence void is inapplicable to the laws mentioned in the $1^{\text {st }}$ Schedule. The land reforms laws are mentioned in this schedule. Hence, this provision is very similar to article 7 of the Interim Constitution. Likewise, article 24 is similar to that of 21 of the Interim Constitution. The rules related to compulsory acquisition of property are inapplicable to any existing law or any law made in pursuance of article 253. The 1972 Regulation is covered under the existing law while the 1977 Act is a law made in pursuance to article 253 of the present constitution. Finally, clause 4 provides that the jurisdiction of courts is barred to determine the adequacy or otherwise of the compensation.

On the basis of the above discussed provisions, the FSC held that it did not have jurisdiction under article 203D to declare these provisions repugnant or otherwise to the injunctions of Islam. Besides, the definition of law as provided in article 203B(c) excludes, inter alia, the Constitution from its ambit. Any attempt to declare the provisions of the Regulation or the Act imposing ceiling on the ownership or possession of property and dealing with compensation repugnant to the injunctions of Islam would ultimately have the effect of declaring articles 24 and 253 of the Constitution repugnant to the injunctions of Islam. This is, of course, beyond the jurisdiction of the FSC and the SAB. What cannot be done directly cannot be done indirectly formed the basis of the opinion of the majority of the FSC.

After referring to all the above constitutional provisions and analyzing them, Aftab Hussain J. believes that the makers of the Constitution have taken all possible steps to protect the land reforms laws from attack of any kind. He says:

This is a unique example of cases in which the framers of the Constitution have taken unusual, rather extraordinary, pains to plug all the loopholes of attack on the vires of the Regulation. They have gone to the extent of declaring even future laws invalid if they abolish or increase the ceiling on ownership of land fixed by the Regulation. ${ }^{(15)}$

One wonders these are the very reasons given by the majority for not exercising jurisdiction with respect to ceiling imposing provisions as the same are enacted under the express command of article 253 of the Constitution for giving effects to the directives contained in articles 37 and 38 of the Constitution. ${ }^{(16)}$

Responding to the contention of the non-obstante clause as used in article 203A, Aftab Hussain J. in his leading judgment asserts that it only provides for exercising jurisdiction under article 203D notwithstanding anything contained in the Constitution. But it cannot be interpreted in any way so as to extend the jurisdiction of the FSC to determine directly or indirectly the repugnancy of any constitutional provision with the injunctions of Islam or to make the same redundant. He said:

The reference to Article 203-A is of no consequence. It only provides for the Court to act notwithstanding anything contained 
in the constitution but it cannot be interpreted as extending its jurisdiction to directly or indirectly determining the repugnancy with Shariah (Islamic law or the injunctions of Islam) of any Constitutional provision or to virtually negating it. ${ }^{(17)}$

Besides, Aftab Hussain J. recalls the presence of a large number of ulema representing different schools of thought in the Parliament which adopted the Constitution unanimously. It is a strong indicative that the powers to be exercised under article 253 for fixing a ceiling on the holding of property by law are not repugnant to the injunctions of Islam. Moreover, a reference is made to Islamī Manshūr (the manifesto) of All Pakistan Jamiat-ul-Ulama-e-Islam. This manifesto provides that the Government can impose a ceiling on holding of land to eradicate social evils and to promote social justice and economic wellbeing of people. The relevant part of this manifesto is produced as follows:

The Shariah has not fixed any maximum limit on the ownership of land but if individual ownership of big tracts of land becomes a cause of mischief in the social economic set up and the social welfare programme and the religious and national interests be in jeopardy or likely to suffer it would be open to the Government to place or fix a limit on the ownership of land in the light of the principles of Shariah. ${ }^{(18)}$

However, Aftab Hussain J. suggests that if there is any conflict between the above discussed two provisions which must be resolved, the same can be done in the light of the Latin maxim "leges posteriores priores contrarias abrogant"(19) i.e. the latter laws abrogate prior contrary laws.

It will not be out of place to recall the observations made by the Supreme Court in Al-Jehad Trust case that if no reconciliation is possible between the conflicting provisions of a constitution, the one present in the original scheme of the Constitution and protecting its vital features is to be preferred to the one inserted by a Martial Law regime. ${ }^{(20)}$

It is worth mentioning that the bar to exercise jurisdiction under article 203D applies only to the provisions pertaining to the fixation of ceiling on the ownership or possession of property and those related to the compensation of surrendered land for the above analysed reasons. There is no such bar with respect to other impugned provisions of the land reforms laws. Notwithstanding the bar of jurisdiction, the FSC with majority of four to one dismissed the Shari'at Petitions thus validating the impugned provisions on merit as well.

Zakaullah Lodhi J. agreed with the majority without discussing the merits of the case. Although he pointed out that he had "different approach on the subject of economic system of Islam. (21)" Conversely, it is quite interesting to observe that in spite of his difference on the issue of jurisdiction with the majority, Durrān̄ $\mathrm{J}$. fully agrees with the leading judgment of Aftab Hussain J. on the issue of fixation of ceiling on the ownership or possession of property on merits. His concluding observations are worth quoting here:

...in spite of my difference of opinion on the ouster of jurisdiction of this Court with my learned brother Sh. Aftab 
Hussain, Member, I fully concur with him on...merits and on the conclusions drawn by him on the concept of Sharia on amassing wealth and property by individuals. All those petition which challenge the provisions of Martial Law Regulation 115 and Land Reforms Act, 1977 to the extent of resumption of private holdings of land for the purpose of Reforms are to be dismissed. ${ }^{(22)}$

The $\mathrm{SAB}$, on the other hand, in appeal held that no provision of the land reforms laws is immune from the jurisdiction under article 203D of the Constitution. Shafiur Rehman J. gave three reasons for exercising jurisdiction under article 203D. These are analysed below.

The first reason relates to the observations made in Said Kamal Shah case. ${ }^{(23)}$ Shafiur Rehman J. was also a member of the Bench who had heard this case. In this case, the SAB had the opportunity to analyse various constitutional provisions providing protection to the land reforms laws. Recalling the observations made in that case, Shafiur Rehman J. holds that these laws are not immune from the jurisdiction under article 203D. In this case it had been held, "To apply this test of repugnancy to the Constitution or a provision thereof is one thing and to apply this test to any other law, validated, continued or protected under the Constitution is another. The first is prohibited, the second is not. (24)"

The second point raised by Shafiur Rehman J. in favour of jurisdiction was that in spite of the comprehensive protection provided to the Land Reforms Regulation, 1972 under article 269 its provisions have been specifically saved from being void on the ground of inconsistency with the fundamental rights under article 8(3) (b). Similarly, if the makers of the Constitution would have wanted to save these provisions from being void on the ground of repugnancy with the injunctions of Islam, a similar provision would have been inserted in chapter $3 \mathrm{~A}$.

However, this reasoning is again unacceptable on at least two grounds. First ground is the same as stated above that the provisions impugned in Said Kamal Shah case had general constitutional protection but no article of the Constitution would become redundant in result of the exercise of the jurisdiction under article 203D. On the other hand, declaring any provision of the land reforms laws that imposes a ceiling on holding of property with or without consideration void would have the effect of making articles 24 (3) (f) and 253 of the Constitution redundant. Thus, the Constitution is excluded from the definition of law as provided in article $203 \mathrm{~B}$ (c) so that the FSC or the SAB cannot declare any constitutional provision void or redundant.

Second ground which is even more logical relates to the interpretation of the injunctions of Islam. One of the purposes of the making of the Land Reforms Regulation, 1972, as has been described in its preamble, is the enforcement of the injunctions of Islam related to the distribution of wealth. ${ }^{(25)}$ So the relevant part of the preamble reads as, "Whereas Islam enjoins equitable distribution of wealth and economic powers and abhors their concentration in a few hands..."(26) This clearly indicates that the makers of the Regulation in their wisdom made a law to enforce the relevant injunctions of Islam. ${ }^{(27)}$ How then would it be possible for 
them to add a provision in chapter 3A to make the 1972 Regulation immune from the jurisdiction which is conferred to declare a law void if held repugnant to the injunctions of Islam?

The third ground asserted by Shafiur Rehman J. for the exercise of jurisdiction under article 203D relates to the scope of the word "law" as used in article 253(2). According to him, law as used in this provision is limited in its meaning to the law made by the Parliament. It does not include judicial pronouncements. Consequently, although the Parliament cannot make a law which allows a person to hold land above the ceiling, there is no such restriction on judicial pronouncements. Interestingly, Shafiur Rehman admits that if the law as used in this provision is held to include judicial pronouncements, the exercise of jurisdiction under article 203D would be in contravention of article 253.

He says, "The two clauses of this Article are coextensive with regard to the source of the law and there is no reason to extend the connotation of law in clause (2) to judicial pronouncements. ${ }^{(28)}$ ",

The second reason forwarded by him is the interpretation of the word law by the Supreme Court in Brig. (Retd.) F. B. Ali case. ${ }^{(29)}$ In this case, the August Supreme Court held with majority that the word law as used in article 9 of the Constitution "is a formal pronouncement of will of competent law-giver. (30)"

The third ground taken in favour of jurisdiction is also not very impressive. The word law as used in article 253(1) mentions the Parliament as a source of law only because it is the primary legislative organ. It is against the concept and scope of legislation that a body primarily intended for legislation is restricted to legislate in a particular field but another organ not primarily intended for legislation is authorized to interfere in the restricted filed. Interestingly, Shafiur Rehman J. despite his different view on jurisdiction agrees with the judgment of the FSC on merits to hold that the provisions of the land reforms laws which impose a ceiling are not repugnant to the injunctions of Islam. He held, "Simply because no such ceiling has actually been fixed in the Holy Quran itself or by Prophet (Peace be upon him) would not be negating the power of the State to fix a limit on distribution of national resources or maximum utilization of it by redistribution. (31)" Similarly, Nasim Hassan Shah J. agrees with the FSC on merits. He holds, "... being of the opinion that on the merits of the case the view of the majority of the Federal Shari'at Court that the impugned laws are not repugnant to the Injunctions of Islam, is correct I would dismiss these appeals... (32)",

\section{Conclusion}

Technically speaking, the Islamic perspective of the land reforms has been judicially determined with all the shortcomings of the judgment in the Qazalbāsh Waqf case. The above analysis of the views of the members of the FSC and the $\mathrm{SAB}$ related to the issue of the jurisdiction reveals that those who asserted that the impugned provisions of the land reforms laws are immune from the jurisdiction have stronger reasons. Similarly, if the collective views of the members of the FSC as well as the SAB related to the merits of the case are considered, it appears that at least six out of ten members hold the view that the provisions of these laws 
pertaining to the fixation of ceiling on holding of property are not repugnant to the injunctions of Islam.

However, the Supreme Court has been approached with the prayer for the determination of the fundamental rights perspective of these reforms. In this regard, it is interesting to note that a constitutional petition No. 97/2011 titled Workers Party Pakistan etc. versus Federation of Pakistan etc. filed under article 184(3) of the Constitution is pending adjudication in the Supreme Court.

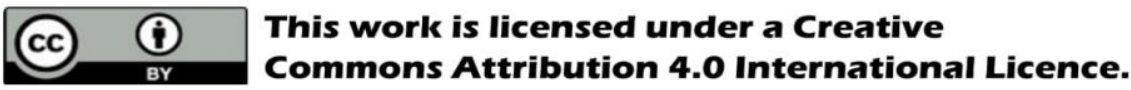

\section{References:}

(1) Qazalbāsh Waqf and others versus Chief Land Commissioner, Punjab, Lahore and others, PLD 1990 Supreme Court 99, Shari'at Appellate Bench]. (Hereinafter referred to as Qazalbāsh Waqf, PLD 1990 SC 99.)

(2) (Qazalbāsh Waqf, PLD 1990 SC 99, 130.)

(3) The basic purpose behind the promulgation of these laws was the abolition of the institution of landlordism and feudalism. Consequently, these laws aimed at eradicating the social evils prevalent pursuant to these institutions and providing social justice to the rural population and their economic wellbeing).

(4) Hafiz Muhammad Ameen etc. versus Islamic Republic of Pakistan and others, PLD 1981 FSC 23 (hereinafter referred to as Hafiz Ameen, PLD 1981 FSC 23), Qazalbāsh Waqf, PLD 1990 SC 99.)

(5) Qazalbāsh Waqf, PLD 1990 SC 99.

(6) Zia-ur-Rehman versus The State, PLD 1972 Lahore 382).

(7) Miss Asma Jilani versus the Government of the Punjab and another, PLD 1972 Supreme Court 139).

(8) Article 280(3) of the Interim Constitution, 1972)

(9) Articles 268 and 269 of the Constitution of the Islamic Republic of Pakistan 1973)

(10) This provision along with the 6th Schedule has been omitted by the 18th constitutional amendment).

(11) Hafiz Ameen, PLD 1980 FSC 23, 60, 65.)

(12) The Land Reform Regulation 1972)

(13) The Land Reforms Act 1977)

(14) The Interim Constitution of 1972)

(15) Hafiz Ameen, PLD 1980 FSC 23, 42.

(16) Article 37 provides for the promotion of social justice and eradication of social evils. It talks about the responsibility of the State with respect to the promotion of educational and economic interests particularly of the backward and depressed classes, removal of illiteracy and to provide educational facilities, availability of justice and others. Importantly, this article enjoins upon the State a duty to make the work conditions friendly and help the people through agricultural development and other methods to play their role in the national life. While article 38 provides for the promotion of social and economic wellbeing of the people as mentioned above. It talks about the responsibility of the State to shield the wellbeing of every class of the society. The State will discharge this responsibility, inter alia, by improving the living standards, equitable distribution 
of wealth and adjustment of rights between land-lords and tenants etc. In fact, this article contains a complete set of social rights. Hafiz Ameen, PLD 1980 FSC 23, 45.

Ibid, 45

(20) Al-Jehad Trust through Raees-ul-Mujahidin Habib-ul-Wahab-ul-Khairi, Advocate Supreme Court and another versus Federation of Pakistan and others, PLD 1997 Supreme Court 84. In this case, the Supreme Court gave its judgment, inter alia, on the irreconcilable conflict between two constitutional provisions i.e. articles $203 \mathrm{C}$ and 209 . The former when it was originally inserted by P.O No. 1 of 1980 under clause 4 provided that a judge of a High Court can be appointed as a member of the FSC for a period of one year without his consent. Besides, clause 5 provided that any such judge who refuses the appointment as a member of the FSC shall cease to hold the position as such judge and will be deemed to have retired from his office. The latter, on the other hand, provided, inter alia, that a judge of the Supreme Court or a High Court shall not be removed from his office except as provided by article 209. It is interesting to note that article 209 did not contain any such ground for the removal of a judge of a High Court as provided in article $203 \mathrm{C}(5)$. Rather, the protection of tenure provided by article 209(7) secured the independence of judiciary. The Court took notice of the fact that the provisions contained in chapter $3 \mathrm{~A}$ have been given an overriding effect over the other provisions of the Constitution. Nonetheless, it went on to observe that article 209 has been provided by the forefathers and framers of the Constitution while article $203 \mathrm{C}$ has been made part of the Constitution by a Martial Law regime. Moreover, the former protected the independence of judiciary and benefitted the judges as compared to the latter. In these circumstances, where reconciliation between two conflicting provisions was not possible the provision inserted in the original scheme of the Constitution and intended to protect a vital feature of the Constitution as compared to the one inserted by a Martial Law regime was preferred.

(21) Hafiz Ameen, PLD 1980 FSC 23, 87-88.

(22) Ibid, 107.

(23) Government of N.W.F.P. through Secretary, Law Department versus Malik Said Kamal Shah, PLD 1986 Supreme Court 360 [Shariat Appellate Bench]. In this case, inter alia, Paragraph 25 (3) (d) of the Land Reforms Regulation, 1972 was declared repugnant to the injunctions of Islam.

(24) Ibid, 466.

(25) Preamble to the Land Reforms Regulation, 1972

(26) See the preamble of the Land Reforms Regulation, 1972 (M.L.R. 115 of 1972)

(28) Ibid, 139.

$$
\text { (rV) }
$$

(29) Brig. (Retd.) F. B. Ali versus the State, PLD 1975 Supreme Court 506.

(30) Ibid.

(31) Qazalbāsh Waqf, PLD 1990 SC 99, 141.

(32) Ibid, 132. 